\author{
Barbara ROSZKOWSKA-MĄDRA, Angelika PARFIENIUK, Marcin \\ STUDNICKI ${ }^{1}$
}

\title{
POGLĄDY MLODZIEŻY AKADEMICKIEJ STUDIÓW EKONOMICZNYCH O PRZEDSIĘBIORCZOŚCI I DETERMINANTACH JEJ ROZWOJU
}

\begin{abstract}
Streszczenie
Celem opracowania jest empiryczne zbadanie poglądów młodzieży akademickiej o zjawisku przedsiębiorczości i czynnikach kształtujących jej rozwój. Badania ankietowe przeprowadzono na próbie losowej stu studentów studiów ekonomicznych. Ich wyniki wykazały, że młodzież akademicka postrzega przedsiębiorczość głównie przez pryzmat nabywanych umiejętności praktycznych (pracy w czasie studiów, praktyk studenckich i innych rodzajów działalności zawodowej), a także przyswajania wiedzy teoretycznej na wykładach i ćwiczeniach. Co więcej, w opinii studentów, ważnym czynnikiem w kształtowaniu się postawy przedsiębiorczej człowieka jest proces jego wychowania, a zwłaszcza wzorce i wartości wyniesione z domu rodzinnego.
\end{abstract}

Słowa kluczowe: przedsiębiorczość, postawy przedsiębiorcze, poglądy o przedsiębiorczości

\section{VIEWS OF ECONOMICS STUDENTS ON ENTREPRENEURSHIP AND FACTORS INFLUENCING ITS DEVELOPMENT}

\section{Summary}

The aim of the paper is to conduct survey research regarding students' views of entrepreneurship as a social phenomenon and the factors affecting its development. The survey was performed on a random sample of a hundred students of economics and related disciplines. The results of the study show that the students perceived entrepreneurship mainly as a collection of acquired practical skills (developed through academic education, student work experience programmes, and other professional activities), as well as during lectures and classes attended at university. Additionally, students thought that the upbringing process - the patterns and values instilled by parents - might be an important determinant of entrepreneurial attitude.

Key words: enterprise, entrepreneurial attitudes, views of entrepreneurship

${ }^{1}$ Dr hab. Barbara Roszkowska-Mądra, prof. UwB - Wydział Ekonomii i Zarządzania, Uniwersytet wBiałymstoku; e-mail:broszkowska@poczta.onet.pl; Angelika Parfieniuk - studentka Wydziału Ekonomii i Zarządzania Uniwersytetu w Białymstoku; e-mail: angelika.parfieniuk@gmail.com; dr Marcin Studnicki adiunkt na Wydziale Rolnictwa i Biologii, Szkoła Główna Gospodarstwa Wiejskiego w Warszawie; e-mail: marcin_studnicki@sggw.pl. 


\section{Wstęp}

Przedsiębiorczość obejmuje szeroki zakres zjawisk: ekonomicznych, społecznych, psychologicznych, etycznych, kulturowych i innych. Zjawiska te kształtują nowe postawy, zachowania i wartości w życiu człowieka. Coraz częściej przedsiębiorczość jest ukazywana w aspekcie nowych aktywności ludzkich wymagających inicjatywy, a nie jedynie stricte w kategorii działalności gospodarczej. Przedsiębiorczość staje się sposobem życia zarówno jednostek gospodarczych, jak i innych uczestników gospodarki, zwłaszcza rynkowej - gospodarstw domowych, instytucji publicznych, stowarzyszeń i innych. Naturalnym twórcą zachowań przedsiębiorczych jest rynek, który wymaga od swoich uczestników przyjęcia przedsiębiorczej postawy [Piecuch, 2010, s. 47], jednego z najważniejszych atrybutów współczesnej gospodarki rynkowej.

Mimo wielokrotnie wykonywanych badań nad przedsiębiorczością i podejmowanych działań, które mają na celu pobudzenie przedsiębiorczych postaw w narodzie, przedsiębiorczość w Polsce jest nadal na niskim poziomie, co stanowi znaczny czynnik ograniczający rozwój gospodarczy i społeczny. Poziom zdolności i wiedzy potrzebnej do założenia działalności gospodarczej w Polsce jest uważany za najsłabiej oceniany obszar w ramach systemu nauczania. Dlatego są konieczne działania, które moga przyczynić się do rozwoju zainteresowania przedsiębiorczością i budowania postaw przedsiębiorczych, szczególnie wśród młodzieży akademickiej [Raport ₹ badania..., 2012]. Aktywność przedsiębiorcza młodzieży akademickiej daje efekty w równej mierze krótkookresowe, czyli ma zasadniczy wpływ na kształtowanie się relacji międzyludzkich na danej uczelni, jak i długookresowe, czyli decyduje o przyszłym kształcie i rozwoju systemu społeczno-gospodarczego, w jakim społeczeństwo będzie funkcjonować w bliższej i dalszej przyszłości.

Ważnym wyzwaniem dla polityki i działalności rządu, instytucji samorządowych, organizacji i stowarzyszeń zawodowych oraz społecznych, a także misji i zadań instytucji naukowych oraz edukacyjnych staje się promowanie przedsiębiorczości i oddziaływanie na kształtowanie się wśród różnych grup społeczeństwa, przede wszystkim wśród młodzieży szkolnej i akademickiej, postaw otwartych na przedsiębiorczość i samozatrudnienie. Doskonalenie wykonywania tych zinstytucjonalizowanych powinności w społeczeństwie demokratycznym przez różne formy zarządzania zewnętrznego wymaga stałego dopływu aktualnej, wiarygodnej i wyczerpującej informacji o stanie myślenia, postrzegania $\mathrm{i}$ traktowania przedsiębiorczości oraz praktyki $\mathrm{w}$ tym zakresie w różnych grupach społeczeństwa, zarówno mającego doświadczenie i dorobek zawodowy, jak i młodzieży akademickiej, która swoje wyobrażenia o praktyce zawodowej i społecznej czerpie z edukacji uniwersyteckiej, doświadczeń rodziny, znajomych, kolegów i własnych, znikomych doświadczeń z rzeczywistościa gospodarcza. Dla nauki i praktyki gospodarczej jest ważna wiedza o poglądach i doświadczeniach zawodowych na przedsiębiorczość podobnie wśród społeczeństwa ze stażem zawodowym, jak i studentów, którzy jeszcze nie mają doświadczenia zawodowego i przez to stanowią swego rodzaju obiekt kontrolny, swoisty stan odniesienia w badaniach nad dynamiką i trajektorią patrzenia na przedsiębiorczość w toku rozwoju zawodowego w zmieniającej się rzeczywistości społeczno-ekonomicznej. Jednocześnie jest istotne poznanie czynników 
determinujących przedsiębiorczość różnych grup społecznych. Ogólnie wiadomo, że czynniki te tkwią zarówno w, szeroko pojętym, otoczeniu (głównie społeczno-kulturowym i polityczno-prawnym) kształtującym postawy przedsiębiorcze, jak i w rozwoju osobowości jednostki. Wobec tego celem przeprowadzonych badań jest empiryczne (za pomoca metody ankietowej) poznanie aktualnych poglądów młodzieży akademickiej, studiującej na kierunkach ekonomicznych, na zjawisko przedsiębiorczości oraz czynników kształtujących jej rozwój. Praca stanowi studium przypadku obejmujące zbiorowość studentów wymienionych kierunków studiów Wydziału Ekonomii i Zarządzania na Uniwersytecie w Białymstoku.

\section{Pojęcie i istota przedsiębiorczości w teorii ekonomii}

Termin przedsiębiorczość pojawił się najprawdopodobniej we Francji około XVI wieku, jednakże nie występował on w powszechnym użyciu czy terminologii ekonomicznej. Dopiero w połowie XVIII wieku Cantillon swoimi studiami nad tym zagadnieniem doprowadził do jego upowszechnienia. W literaturze przedmiotu nie ma jednoznacznego stanowiska wobec definicji przedsiębiorczości [Casson, Yeung, Basu, Wadeson, 2009, s. 3]. Jest ona najczęściej przedstawiana jako cecha lub proces. W podejściu skupiającym się na właściwościach jednostki są brane pod uwagę jej cechy zarówno wrodzone, jak i nabyte. Wśród wrodzonych wymienia się: wrodzone przywództwo, odwagę w podejmowaniu trudnych i ryzykownych decyzji, bystrość umysłu. Cechy te, zdaniem Strużyckiego, moga zostać wzmocnione przez edukację, a w sprzyjających okolicznościach mogą również wykształcić się u ludzi, którzy ich nie posiadają [BrajerMarczak, Marciszewska, za: Strużycki, 2008, s. 170]. Podejście procesowe opisuje przedsiębiorczość jako sprzężenie działań na trzech płaszczyznach, a mianowicie w zakresie: myślenia (pojmowania potrzeby zmian), funkcjonowania (radzenia sobie w warunkach zmieniającego się otoczenia) i uzyskanych rezultatów (efektów instytucjonalnych) podjętych działań.

W polskim ustawodawstwie mianem przedsiębiorczości określa się zakładanie i prowadzenie własnej działalności gospodarczej. Definicja ta jest dosyć wąska, gdyż nie oddaje całego spektrum znaczeń przypisywanych omawianemu pojęciu. Natomiast, w szerszym rozumieniu, przedsiębiorczość można zdefiniować przede wszystkim jako tworzenie nowych wartości przez poświęcenie własnego czasu, wysiłku fizycznego i umysłowego oraz przyjęcie finansowego, psychicznego i fizycznego ryzyka, które w efekcie powoduje wypracowanie zysku w postaci pieniężnej, jak i poczucia osobistej satysfakcji i niezależności. W związku z powyższym, to właśnie przedsiębiorczość i przedsiębiorcy odgrywają istotną rolę w procesie kształtowania i rozwoju gospodarki każdego kraju [Borkowski, 2012, s. 111]. Pojęcie przedsiębiorczości jest na tyle trudne

2 Traktuje się ją w odniesieniu do: cech osobowych, umiejętności, talentu, motywacji i systemu wartości. 
w zdefiniowaniu, że w zależności od badacza jest ono przedstawiane na wzór jego zainteresowań i posiadanej wiedzy.

Jako pierwszy słowa ‘przedsiębiorca' w znaczeniu, jakie jest znane dzisiaj, użył Say. Określił on, że przedsiębiorca przenosi zasoby ekonomiczne z obszarów o mniejszej wydajności do obszarów o większej produktywności, odnosząc przy tym większe korzyści ekonomiczne. Przedsiębiorczość, według takiego rozumienia, stanowi zespół wyjątkowych umiejętności posiadanych przez przedsiębiorcę, centralną postać gospodarki. Umiejętności te obejmują między innymi ponadprzeciętną skłonność do podejmowania ryzyka oraz chęć wzbogacenia się [Entrepreneurship, 2009]. Odmienne podejście reprezentował, jeden z najczęściej cytowanych teoretyków przedsiębiorczości, Schumpeter, dla którego przedsiębiorczość była uwarunkowana przede wszystkim innowacjami: tworzeniem nowych gałęzi przemysłu czy wymuszaniem zmian w gospodarce [Casson, Yeung, Basu, Wadeson, 2009, s. 3]. Nie postrzegał on osób przedsiębiorczych jedynie przez pryzmat maksymalizowania zysku, ale jako jednostki działające instynktownie, kierujące się wewnętrzną motywacją [Parker, 2009, s. 34]. W analizie dokonanej przez Schumpetera osoby przedsiębiorcze były wyraźnie ukierunkowane na wprowadzanie zmian, które są naturalnym i nieodłącznym atrybutem działania przedsiębiorców. Współczesne definicje przedsiębiorczości często opierają się na wspomnianych aspektach analizy [Drozdowski, 2014]. Drucker kontynuował myśl Schumpetera, równie i silnie akcentując znaczenie innowacji - przypisał jej funkcję zalążka zachowań przedsiębiorczych [Drucker, 1992, s.7-9].

Natomiast Knight zwrócił uwagę na znaczenie ryzyka i niepewności w otoczeniu i świadomości przedsiębiorcy, które wynika z jego ograniczonych informacji o dostępności źródeł surowców, zmianach technologicznych, jak i cenach ${ }^{3}$. Zatem, według niego, aby sprawnie funkcjonować w takich warunkach, należy posiadać szczególne cechy, takie jak: wiara w siebie, umiejętność dokonywania trafnej oceny i wyborów, śmiałość, umiejętność przewidywania, a także szczęście. Przedstawione cechy, zdaniem Knighta, są więc niezbywalne - tworzą uzupełnienie innych, posiadanych atutów i środków. Osoby przedsiębiorcze dążą do wykorzystania posiadanych, wyjątkowych cech. Od podejścia do ryzyka i względnych korzyści zależy zatem decyzja, czy dana jednostka stanie się przedsiębiorca, czy też nie [Parker, 2009, s. 32-33].

W ujęciu Kirznera, udana działalność przedsiębiorcza odgrywa niezwykle istotna rolę w pobudzaniu wzrostu i rozwoju gospodarczego. Ważnym aspektem tego rozwoju jest ukierunkowanie na identyfikację cech charakteru, które przyczyniają się do sukcesu przedsiębiorców, lecz również uwzględnienie warunków społecznych i ekonomicznych, które oddziałują na budowę zachowań i rozwój udanych działań przedsiębiorczych [Kirzner, 2008].

Równocześnie polscy naukowcy wykazują zainteresowanie przedsiębiorczością. Pietraszewski określa przedsiębiorczość jako nowatorstwo odznaczające się poszukiwaniem wyjątkowości i odmienności w tym, co robią inni. To poszukiwanie skuteczniejszych sposobów na realizację zamierzonych działań daje osobom przedsiębiorczym wyższą uży-

3 Ceny czynników produkcji można ustalić, jednakże popyt konsumencki i działania konkurentów mogą znacznie i nieprzewidywalnie zmieniać się, stąd też ceny wyjściowe ulegają wahaniom. 
teczność oraz efektywność gospodarowania [Pietraszewski, 2002, s. 11]. Zdaniem Bartnickiego i Strużyny, przedsiębiorczość jest sposobem bycia, który stanowi proces na tyle złożony, że można go ują́ jako odmienny typ: postrzegania świata, myślenia i działania, pozwalający przedsiębiorcy na kreowanie i wykorzystywanie dostrzeganych szans rozwojowych [Bratnicki, Strużyna, 2004, s. 179-190].

\section{Przedsiębiorczość w badaniach naukowych}

Badania nad przedsiębiorczością i podejmowaniem działań, które mają na celu pobudzenie przedsiębiorczych postaw w narodzie, podejmowano wielokrotnie zarówno w kraju, jak i za granica. Wyniki przeprowadzonych badań dowodza, że budowanie postaw przedsiębiorczych w społeczeństwie jest bardzo ważnym czynnikiem stymulującym rozwój społeczno-gospodarczy4. Natomiast wyniki międzynarodowego projektu Global Entrepreneurship Monitor (GEM) przeprowadzonego w obszarze przedsiębiorczości w 2011 roku, do którego realizacji przystapiła Polska Agencja Rozwoju Przedsiębiorczości we współpracy z Uniwersytetem Ekonomicznym w Katowicach, wykazały, że w Polsce studenci pod względem przedsiębiorczości są najgorzej oceniana grupa społeczną [Entrepreneurship, 2009]. Stwierdzono, że nauczanie przedsiębiorczości w Polsce jest niezadowalające i cechuje je zbyt niski poziom. To zaś stawia niezwykle trudne wyzwania przed polityka, na różnych szczeblach zarządzania, w zakresie wspierania przedsiębiorczości i oddziaływania na kształtowanie postaw przedsiębiorczych wśród społeczeństwa. Niestety, wyniki przeprowadzonych badań nie wskazuja, które elementy uwarunkowań są istotne w budowaniu postaw przedsiębiorczych i w jaki sposób czynniki te rozwijać tak, aby pobudzać aktywność przedsiębiorczą młodzieży akademickiej. Fakt ten stanowi zachętę dla badaczy w kwestii wypełnienia luki badawczej.

Porównując wyniki badań ogólnopolskich z sąsiednimi krajami, uznano, że aktywność młodzieży akademickiej w naszym kraju jest najniższa. Z drugiej strony wskaźniki TEA ${ }^{5}$ i odsetek dojrzałych firm są w kraju najwyższe dla osób z wyższym wykształceniem, co świadczy o doniosłym znaczeniu zasobów niematerialnych (umiejętności) w efektywnym prowadzeniu działalności gospodarczej [Prz̨edsiębiorczość akademicka. Raport z badania, 2009]. Taką tezę potwierdza teoria zasobowa firmy, która umiejętnościom przypisuje szczególne znaczenie w rozwoju przedsiębiorstwa. Według niej, są to niezbędne zasoby do tworzenia i utrzymywania przewagi konkurencyjnej przedsiębiorstwa na rynku [Noga, 2009]. Niski poziom edukacji, szczególnie początkowej (co nierzadko ma miejsce na obszarach wiejskich) jest często wskazywaną bariera, która ogranicza ich rozwój przedsiębiorczości [Marciniak, 2011]. Badania przeprowadzone przez Wawrzyniak wykazały znaczący związek między poziomem edukacji

${ }^{4}$ Na przykład: [Cotis, 2007; Carree, Thurik; Raport o stanie sektora..., 2010].

${ }^{5}$ Jest to całkowita przedsiębiorczość we wczesnym stadium (ang. Total early-stage Entrepreneurial Activity - TEA). Nie mierzy ona przy tym udziału ludności prowadzącej działalność gospodarcza, a jedynie zakładającą działalność i prowadząca ją we wczesnym stadium [Dokument elektroniczny, tryb dostępu: [http://www.parp.gov.pl, data wejścia: 28.12.2013]. 
a skłonnością do przedsiębiorczości, innowacyjności oraz ujawniania potrzeby korzystania z informacji i środków teleinformatycznych [Wawrzyniak, 2001, s. 143]. Zdobyta wiedza wpływa na rozwój cech osobowościowych człowieka (samodzielność, kreatywność, umiejętność współpracy, umiejętność wyszukiwania i efektywnego wykorzystywania potrzebnych informacji). Zatem decyduje ona o wzroście przedsiębiorczości osobistej. Zdaniem Bienioka, przedsiębiorczość osobista jest funkcją co najmniej kilku istotnych czynników, a mianowicie: genów, odpowiedniego poziomu inteligencji ogólnej i emocjonalnej, wykształcenia, wiedzy oraz motywacji. Bez motywacji w działaniu ludzkim nawet silne predyspozycje genetyczne, wysoki iloraz inteligencji oraz znacząca wiedza, a także wysoki poziom zdobytego wykształcenia moga nie stać się stymulantami przedsiębiorczości. Według badacza, kluczowym czynnikiem sprawczym przedsiębiorczości jest kultura wychowania w rodzinie, w szkole czy w trakcie studiów, polegająca na przyswojeniu sobie filozofii: inicjatywy, aktywności, zaradności i wzajemnej pomocy [Bieniok 2007, s. 224-235].

Aktywność przedsiębiorcza młodzieży akademickiej ma zasadniczy wpływ na kształtowanie się zarówno relacji międzyludzkich na danej uczelni, jak i wzrost oraz rozwój gospodarczy kraju. Od młodzieży zależy przyszła postać i rozwój systemu społeczno-gospodarczego, w jakim społeczeństwo będzie funkcjonować. Zgodnie z raportem Polskiej Agencji Rozwoju Przedsiębiorczości (PARP) pt.: Przedsiębiorczość akademicka $w$ Polsce, wyzwaniem dla instytucji naukowych i edukacyjnych staje się m.in. kształtowanie wśród studentów postaw otwartych na przedsiębiorczość i samozatrudnienie, ponieważ przedsiębiorczość ta jest wciąż na niewystarczającym poziomie [Przedsiębiorczość akademicka. Raport z badania, 2009]. W badaniach Polskiej Agencji Rozwoju Przedsiębiorczości poszukiwano odpowiedzi na wiele interesujących pytań, m.in. dotyczących wpływu programów studiów na rozwój przedsiębiorczości akademickiej czy oceny praktyk zawodowych studentów [Przedsiębiorczosíc akademicka. Raport z badania, 2009]. Ich zakres nie wydał się w pełni dostateczny, bowiem nie skupiono się w sposób dogłębny na omawianych zagadnieniach. Oceniono przydatność nauczania przedsiębiorczości czy występowanie oferty programowej zawierającej przedmioty związane z przedsiębiorczością, ale w sposób zbyt ogólny. Wyniki okazały się niedostatecznym materiałem naukowym, aby móc określić, jakie są uwarunkowania postaw przedsiębiorczych młodzieży akademickiej i jakie zadania powinny być podejmowane przez uczelnie wyższe.

Przedsiębiorczość jest zjawiskiem mierzalnym. Jej pomiar może być dokonywany według różnych kryteriów: liczby (frakcji) osób rozpoczynających działalność typu small business oraz oceny klimatu przedsiębiorczości (czynników utrudniających i ułatwiających rozwój przedsiębiorczości) na danym obszarze. Natomiast do tych można zaliczyć: istniejące unormowania prawne, wsparcie instytucjonalne, poziom wiedzy, a także postawy przedsiębiorcze (ang. Entrepreneurial attitudes), [Kłosowski , Bagiński, 2013], które są przedmiotem szczegółowych analiz zawartych w niniejszym opracowaniu. 


\section{Materiał i metodyka badań}

Badania nad wpływem kilku charakterystyk młodzieży akademickiej na ich poglądy (opinie) dotyczące istoty przedsiębiorczości oraz czynników warunkujących postawę przedsiębiorczą człowieka przeprowadzono na grupie studentów studiów dziennych Wydziału Ekonomii i Zarządzania Uniwersytetu w Białymstoku w maju 2013 roku. Dobór do grupy badawczej prowadzono w sposób losowy. W badaniach wykorzystano metodę ankietowa którą objęto 100 studentów tego wydziału. Największą grupę objętych badaniem stanowili studenci kierunku Ekonomia - 57\%, natomiast studenci kierunku Zarządzanie i Międzynarodowe Stosunki Gospodarcze tworzyli podobny udział w strukturze osób biorących udział w badaniu, który wynosił odpowiednio: 21\% i 22\%. Próba badawcza stanowiła blisko 7\% wszystkich studentów Wydziału Ekonomii i Zarządzania. Kwestionariusz ankiety skierowany do osób biorących udział w badaniu był anonimowy i miał konstrukcję zamknięta. Struktura badanej grupy studentów kształtowała się następująco: 70\% ankietowanych stanowiły kobiety, a 30\% mężczyźni. Dominująca grupa wiekową były osoby w wieku 21-23 lata - 56\% ankietowanych, uczestnicy badań w wieku 18-20 lat stanowili 34\% ankietowanych, zaś w wieku 24-26 lat$10 \%$. W wylosowanej grupie badawczej $60 \%$ ankietowanych osób pochodziło ze wsi, a $40 \%$ z miasta.

Do badania zgodności rozkładu prawdopodobieństw rodzajów poglądów studentów ze względu na swoje postrzeganie przedsiębiorczości lub przyczyny jej rozwoju w badanych grupach odpowiadajacych rozpatrywanym charakterystykom studentów (determinantom badanych poglądów, tj.: płeć, pochodzenie, wiek i kierunek studiów) zastosowano test Chi-kwadrat. Przyjęto, że jeżeli dla funkcji testowej tego testu $\mathrm{p}<0,05$, to znaczy, że stwierdzono niezgodność rozkładu prawdopodobieństw w określonej zmiennej wynikowej (rodzaju poglądu) w badanych grupach studentów.

Do badania wpływu określonych determinant (płeć, pochodzenie, wiek i kierunek studiów) na rodzaj poglądów studentów na temat postrzegania przedsiębiorczości lub przyczyn jej rozwoju zastosowano test niezależności Chi-kwadrat. Przyjęto, że jeżeli dla zastosowanej statystyki tego testu poziom istotności będzie mniejszy od poziomu krytycznego $(\mathrm{p}<0,05)$, wówczas zostanie stwierdzony wpływ określonego czynnika na rodzaj poglądu w badanych grupach studentów.

\section{Wyniki badań związanych z uwarunkowaniami rozkładu częstości poglądów studentów o przedsiębiorczości}

\subsection{Sposób swojego postrzegania zjawiska przedsiębiorczości}

Zastosowany test Chi-kwadrat wykazał istotną niezgodność $(\mathrm{p}=0,0027)$ rozkładu prawdopodobieństw $\mathrm{w}$ zakresie sposobu postrzegania zjawiska przedsiębiorczości w grupach studentów według płci. Zatem płeć jest determinantem warunkującym rozkład poglądów studentów o postrzeganiu przez nich przedsiębiorczości. Zastosowany test Chi-kwadrat wykazał istotną statystycznie zależność $(\mathrm{p}=0,0027)$ między płcią a sposobem postrzegania zjawiska przedsiębiorczości w grupach studentów. Zatem, płeć jest 
czynnikiem warunkującym empiryczny rozkład poglądów studentów o postrzeganiu przez nich przedsiębiorczości. Wyniki przeprowadzonych badań wykazały, że studenci najczęściej uznawali przedsiębiorczość jako umiejętność. Jednakże znacznie częściej (o około 20 p.p.), pogląd ten wyrażały kobiety niż mężczyźni (rysunek 1a). Znacząca była także różnica w częstości traktowania przedsiębiorczości jako zachowania u obu płci, które było uznawane jako symptom przedsiębiorczości zaledwie przez 6\% ankietowanych kobiet i aż 1/3 zbiorowości mężczyzn. Dwukrotnie częściej kobiety niż mężczyźni postrzegali postawę jako symptom przedsiębiorczości. Przedsiębiorczość była najrzadziej postrzegana jako proces, tak uważało około 5\% ankietowanych w każdej grupie ze względu na płeć.

RYSUNEK 1.

Rozkłady częstości poglądów młodzieży akademickiej o własnym postrzeganiu przedsiębiorczości, zależnie od: płci (a), miejsca pochodzenia (b), wieku (c) oraz kierunku studiów (d)

(a)

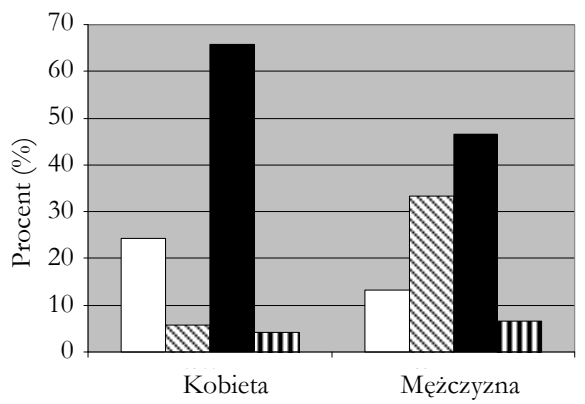

(c)

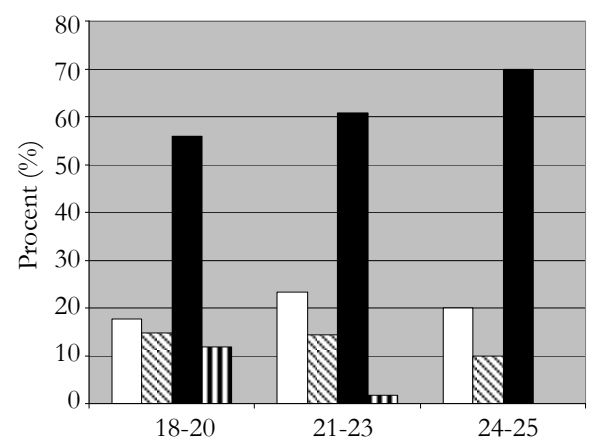

(b)

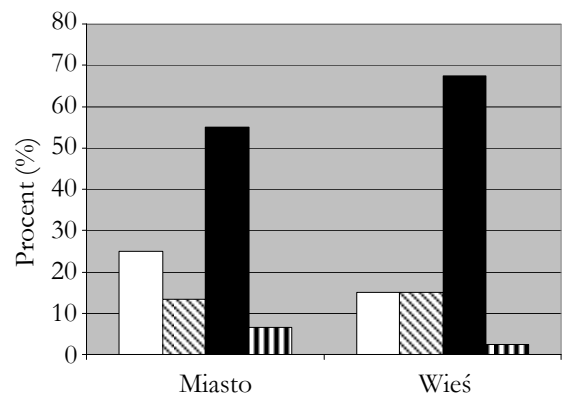

(d)

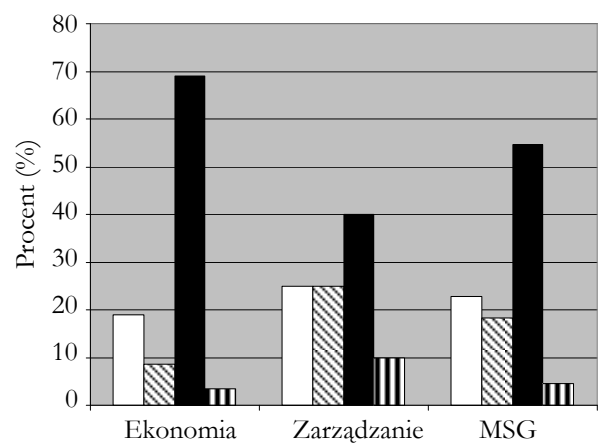

Umiejętność I Proces

Źródło: opracowanie własne.

Test Chi-kwadrat nie wykazał istotnej niezgodności $(\mathrm{p}=0,449)$ rozkładu prawdopodobieństw $\mathrm{w}$ zakresie sposobu postrzegania zjawiska przedsiębiorczości $\mathrm{w}$ gru- 
pach studentów według miejsca ich pochodzenia (rysunek 1b), wieku (rysunek 1c) oraz kierunku studiów (rysunek 1d). Test Chi-kwadrat nie wykazał istotnej zależności w zakresie sposobu postrzegania zjawiska przedsiębiorczości w grupach studentów według miejsca ich pochodzenia (rys.1b), wieku (rys.1c) oraz kierunku studiów (rys.1d). Wyniki wskazują że wszystkie te trzy czynniki nie różnicuja poglądów studentów o postrzeganiu przez nich przedsiębiorczości. Zatem miejsce pochodzenia, wiek oraz kierunek studiów nie były determinantami warunkującymi rozkład poglądów studentów o postrzeganiu przedsiębiorczości. Studenci niezależnie od miejsca ich pochodzenia, wieku oraz kierunku studiów uznawali przedsiębiorczość głównie jako umiejętność i taki pogląd wyrażało około $60 \%$ studentów. Przedsiębiorczość jako zachowanie i postawa była traktowana z tą samą częstością (około 15\% ankietowanych) niezależnie od wariantów badanych czynników. Przedsiębiorczość była najrzadziej uważana jako proces i nie zależało to od tych czynników (ten pogląd wyraziło około $5 \%$ ankietowanych).

\subsection{Stopień przekonania o własnej przedsiębiorczości}

Test Chi-kwadrat wykazał istotna niezgodność $(\mathrm{p}=0,01)$ rozkładu prawdopodobieństw pod względem stopnia przekonania o własnej przedsiębiorczości w grupach studentów według płci. Test Chi-kwadrat wykazał istotną zależność $(\mathrm{p}=0,01)$ między płcią a stopnia przekonania o własnej przedsiębiorczości w grupach studentów. Zatem płeć jest czynnikiem warunkującym rozkład stopnia poczucia własnej przedsiębiorczości. Najczęściej były wyrażane poglądy studentów o tym, że są oni raczej przedsiębiorczy. Jednakże znacznie częściej (o 20 p.p) pogląd ten wyrażały kobiety niż mężczyźni (rysunek 2a). Znacząca była różnica (o 19 p.p) w częstości wyraźnego przekonania studentów o własnej przedsiębiorczości i częściej bardzo zdecydowani w samoocenie o przedsiębiorczości byli mężczyźni niż kobiety. Zarówno brak zdecydowania w wyrażaniu przekonania studentów o własnej przedsiębiorczości, jak i niedostrzeganie przez nich w sobie ducha przedsiębiorczości występowało z podobną częstością u obu płci.

Nie wykazano istotnej niezgodności $(\mathrm{p}=0,22)$ rozkładu prawdopodobieństw pod względem stopnia przekonania o własnej przedsiębiorczości w grupach studentów wedlug miejsca pochodzenia. Nie wykazano istotnej zależności $(\mathrm{p}=0,22)$ stopnia przekonania o własnej przedsiębiorczości w grupach studentów według miejsca pochodzenia. Stąd ten jeden czynnik, spośród czterech badanych, nie różnicuje rozkładu prawdopodobieństw poglądów studenckich dotyczacych stopnia przekonania o własnej przedsiębiorczości, czyli nie warunkuje on stopnia poczucia własnej przedsiębiorczości w badanej populacji studentów. Studenci, niezależnie od miejsca ich pochodzenia, najczęściej uznawali, że są raczej przedsiębiorczy. Taki pogląd wyrażało około 45\% studentów (rysunek 2b). Częstość wyrażania pozostałych stopni poczucia własnej przedsiębiorczości, niezależnie od miejsca pochodzenia studentów, kształtowała się na poziomie około $10 \%$

Stwierdzono istotną niezgodność $(\mathrm{p}=0,02)$ rozkładu prawdopodobieństw pod względem stopnia przekonania o własnej przedsiębiorczości w wiekowych grupach stu- 
dentów. Stwierdzono istotna zależność $(\mathrm{p}=0,02)$ między wiekiem a stopniem przekonania o własnej przedsiębiorczości. Wobec tego wykazano, że wiek studentów warunkuje stopień przekonania o własnej przedsiębiorczości. Wraz ze wzrastającym wiekiem studentów zmniejszała się częstość wyrażania opinii raczej bycia przedsiębiorczym (od 50 do $25 \%$ ), zaś bardzo zwiększyła się częstość wyrażania opinii bycia przedsiębiorczym (od 5 do 50\%) - (rysunek 2c).

RYSUNEK 2.

Rozkłady częstości poglądów młodzieży akademickiej o własnej przedsiębiorczości, zależnie od: płci (a), miejsca pochodzenia (b), wieku (c) oraz kierunku studiów (d)

(a)

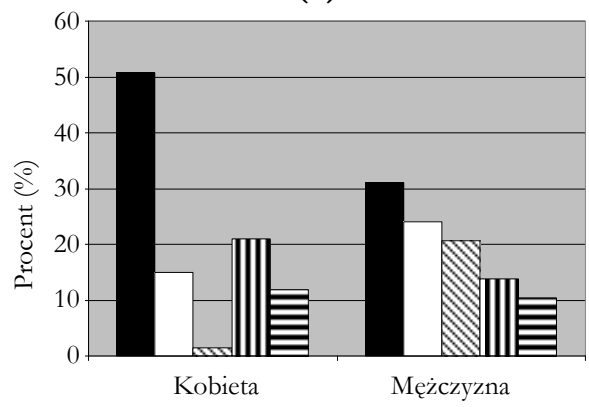

(c)

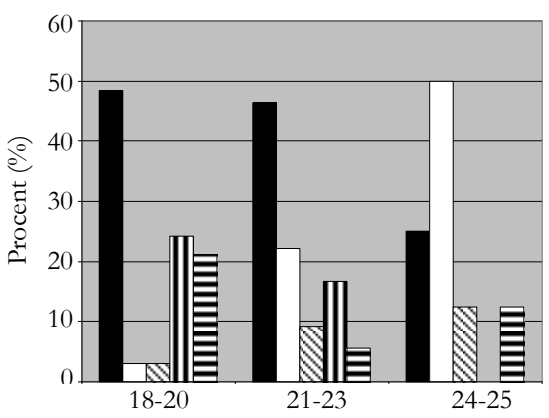

raczej tak 向 raczej nie (b)

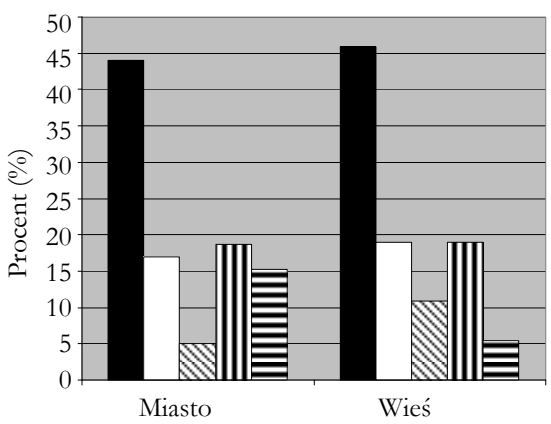

(d)

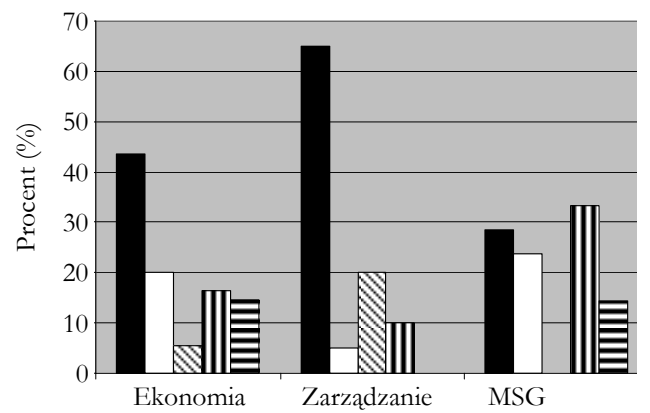

¿ zdecydowanie tak

Źródło: opracowanie własne.

Wykazano także istotną niezgodność ( $\mathrm{p}=0,0221)$ rozkładu prawdopodobieństw pod względem rozpatrywanego rodzaju poglądów o własnej przedsiębiorczości studentów w zależności od kierunku studiów. Wykazano także istotną zależność $(\mathrm{p}=0,0221)$ między kierunkiem studiów a poglądami o własnej przedsiębiorczości studentów. Wskazuje 
to na uwarunkowanie stopnia przekonania o własnej przedsiębiorczości studentów przez kierunek studiów. Stwierdzono największe różnice częstości wyrażania opinii raczej bycia przedsiębiorczym (od 30\% na kierunku MSG do 65\% na kierunku Zarządzanie) (rysunek 2d). Ponadto studenci kierunku MSG wyrażali najczęściej opinię raczej niebycia przedsiębiorczym (około 30\%), zaś około 3 razy rzadziej tę opinię wyrażali studenci kierunków Ekonomia i Zarządzanie. Z wykazanej specyfiki rozkładu częstości poglądów o stopniu poczucia przedsiębiorczości studentów można wnioskować, że studenci tradycyjnie ekonomicznych kierunków mają w znacznie większym stopniu poczucie własnej przedsiębiorczości niż studenci nowych kierunków ekonomicznych, takich jak kierunek MSG.

Wyniki przeprowadzonych badań wykazały, że miejsce pochodzenia studentów nie jest determinantem, zaś płeć, wiek i kierunek studiów są determinantami warunkującymi rozkład poglądów studentów dotyczących stopnia poczucia własnej przedsiębiorczości.

\subsection{Pogląd o wpływie edukacji na przedsiębiorczość}

Nie stwierdzono istotnej niezgodności rozkładu prawdopodobieństw pod względem poglądów studentów o wpływie edukacji na przedsiębiorczość w grupach ze względu na: płeć $(p=0,13)$, wiek $(p=0,81)$, miejsce pochodzenia $(p=0,64)$ i kierunek studiów $(\mathrm{p}=0,33)$. Zatem wykazano, że płeć, wiek, miejsce pochodzenia i kierunek studiów nie są determinantami warunkującym rozkład stopnia poglądów studentów o wpływie edukacji na rozwój przedsiębiorczości.

Nie stwierdzono istotnej zależności między poglądami studentów o wpływie edukacji na przedsiębiorczość a płcią $(\mathrm{p}=0,13)$, wiekiem $(\mathrm{p}=0,81)$, miejscem pochodzenia $(\mathrm{p}=0,64)$ czy kierunkiem studiów $(\mathrm{p}=0,33)$. Zatem wykazano, że płeć, wiek, miejsce pochodzenia i kierunek studiów nie są determinantami warunkującym rozkład stopnia poglądów studentów o wpływie edukacji na rozwój przedsiębiorczości.

Studenci, niezależnie od wszystkich analizowanych czynników, z podobną częstością (ponad 90\% wszystkich ankietowanych) wyrażali pogląd, że edukacja ma wpływ na poziom przedsiębiorczości. Pogląd o braku wpływu edukacji na przedsiębiorczość był również wyrażany z podobna częstościa przez studentów zarówno według płci, wieku, miejsca pochodzenia, jak i kierunku studiów (około 8\% ankietowanych). Wraz ze wzrastającym wiekiem ankietowanych zwiększała się częstość pozytywnych opinii o wpływie edukacji na przedsiębiorczość. Studenci w wieku 24-26 lat jednogłośnie stwierdzili, że istnieje wpływ edukacji na przedsiębiorczość. Taką sama pozytywna opinię w tej kwestii wyraziło 100\% ankietowanych studentów kierunku Zarządzanie. 
RYSUNEK 3.

Rozkłady częstości poglądów młodzieży akademickiej o wpływie edukacji na przedsiębiorczość, zależnie od: płci (a), miejsca pochodzenia (b), wieku

(c) oraz kierunku studiów (d)

(a)

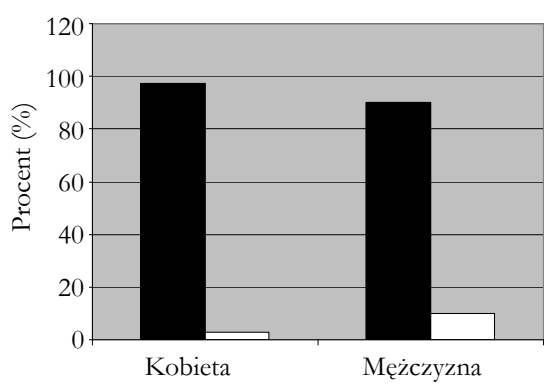

(c)

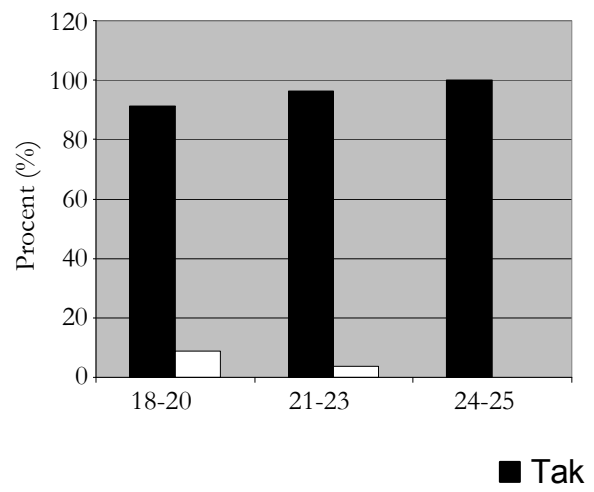

(b)

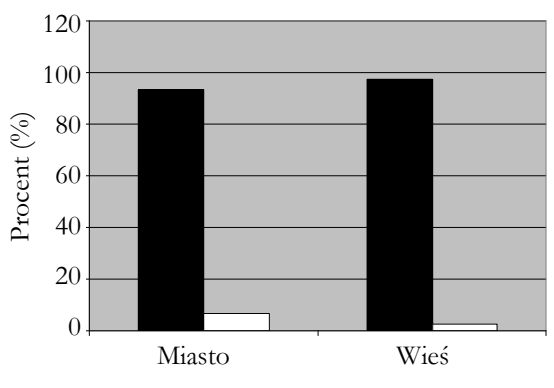

(d)

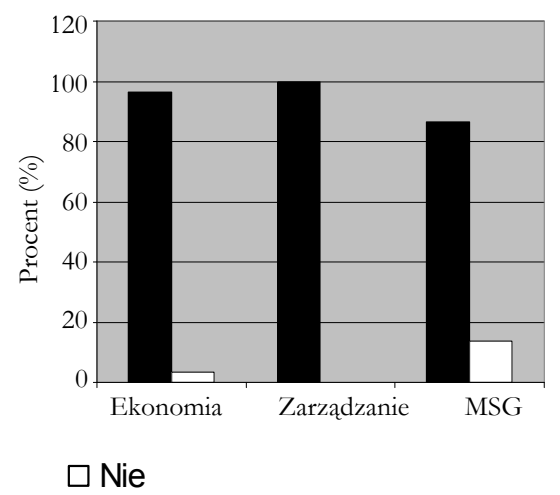

Źródło: opracowanie własne.

\subsection{Pogląd o wpływie władz rządowych i samorządowych na przedsiębiorczość}

Zastosowany test Chi-kwadrat nie wykazał istotnej niezgodności rozkładu prawdopodobieństw poglądów studentów o wpływie władz rządowych i samorządowych na przedsiębiorczość w grupach ze względu na: płeć ( $\mathrm{p}=0,54)$, (rysunek 4a), miejsce pochodzenia $(\mathrm{p}=0,94)$, (rysunek $4 \mathrm{~b})$, wiek $(\mathrm{p}=0,22)$, (rysunek $4 \mathrm{c})$ i kierunek studiów $(\mathrm{p}=0,48)$, (rysunek $4 \mathrm{~d})$. Zastosowany test Chi-kwadrat nie wykazał istotnej zależności między poglądami studentów o wpływie władz rządowych i samorządowych na przedsiębiorczość a płcia $(\mathrm{p}=0,54)$ - (rys. 4a), miejscem pochodzenia $(\mathrm{p}=0,94-(\mathrm{rys} .4 \mathrm{~b})$, wiekiem $(\mathrm{p}=0,22)-($ rys. $4 \mathrm{c})$ iczy kierunkiem studiów $(\mathrm{p}=0,48)-($ rys. 4d) Zatem wykazano, że płeć, wiek, miejsce pochodzenia i kierunek studiów nie są determinantami warunkującym rozkład poglądów studentów o wpływie władz rządowych i samorządowych na przedsiębiorczość. Niezależnie od wszystkich analizowanych czynni- 
ków, studenci z podobną częstością (blisko 90\% wszystkich ankietowanych) wyrażali pogląd, że władze rządowe i samorządowe mają wpływ na poziom przedsiębiorczości. Pogląd o braku ich wpływu na przedsiębiorczość wyrażało blisko 10\% wszystkich ankietowanych studentów. Największe zróżnicowanie (o 12 p.p.) w częstości wyrażanych opinii studentów (według kierunku studiów) na temat wpływu władz na przedsiębiorczość wystapiło wśród studentów kierunku MSG, natomiast 18\% studentów tego kierunku nie dostrzegało takiego wpływu.

RYSUNEK 4.

Rozkłady częstości poglądów młodzieży akademickiej o wpływie władz rządowych i samorządowych na przedsiębiorczość, zależnie od: płci (a), miejsca pochodzenia (b), wieku (c) oraz kierunku studiów (d)

(a)

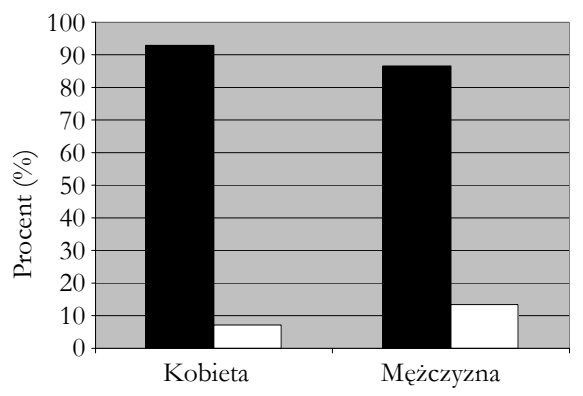

(c)

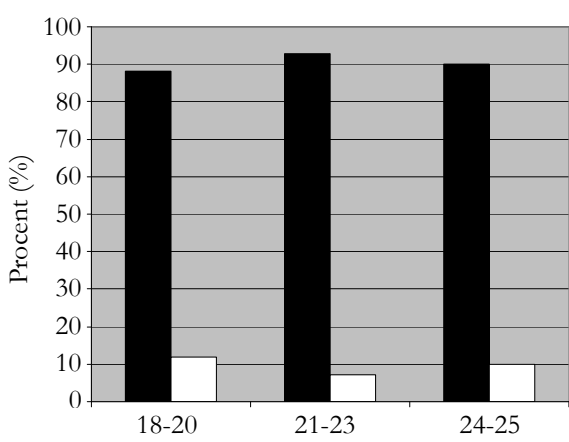

(b)

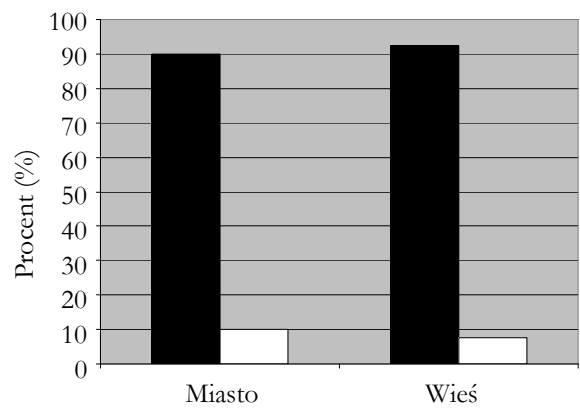

(d)

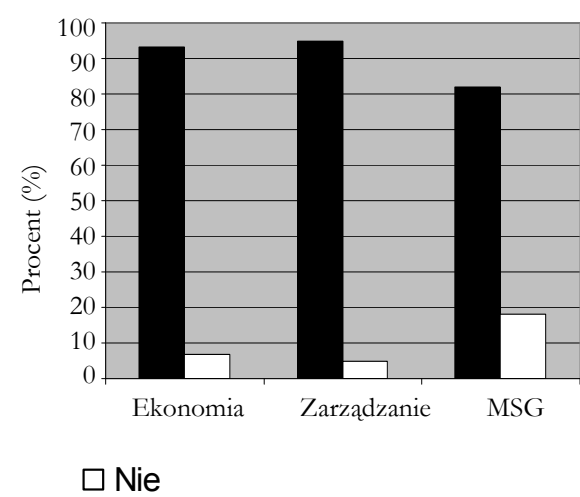

Źródło: opracowanie własne. 


\section{Wyniki badań związanych z rozkładem częstości poglądów studentów o najważniejszych czynnikach kształtujących przedsiębiorczość}

W tym rozdziale przedstawiono wyniki badań przeprowadzonych na łącznej próbie 100 studentów, bez uwzględnienia ich podziału na wcześniej rozpatrywane grupy.

\subsection{Pogląd o wpływie wychowania w rodzinie na przedsiębiorczość}

W zdecydowanej większości ( $87 \%$ ankietowanych studentów) wyrażano pogląd, że na kształtowanie się postawy przedsiębiorczej człowieka wpływa proces jego wychowania $\mathrm{w}$ rodzinie. Według ankietowanych studentów, najważniejszymi składnikami wychowania w rodzinie dla kształtowania przedsiębiorczości były najczęściej posiadanie przez rodzica lub innego członka rodziny własnej firmy $(27,6 \%)$, relacje rodzinne/kontakty międzyludzkie i wykonywane obowiązki w domu (25,3\%), zaś znacznie rzadziej, odnoszenie się do innych ludzi $(9,2 \%)$, autorytet rodzica $(6,9 \%)$, wzajemne wspieranie się $(4,6 \%)$ oraz kultywowane tradycje $(1,1 \%)$ - (rysunek 5.). Wynika z tego, że dużą rolę w kształtowaniu postaw przedsiębiorczych należy przypisać instytucjom nieformalnym, do których jest zaliczana rodzina. Poglądy te znajduja potwierdzenie w wynikach badań wielu autorów ${ }^{6}$.

RYSUNEK 5.

Rozkład częstości poglądów młodzieży akademickiej o najważniejszych składnikach wychowania w rodzinie wpływających na kształtowanie się postaw przedsiębiorczych

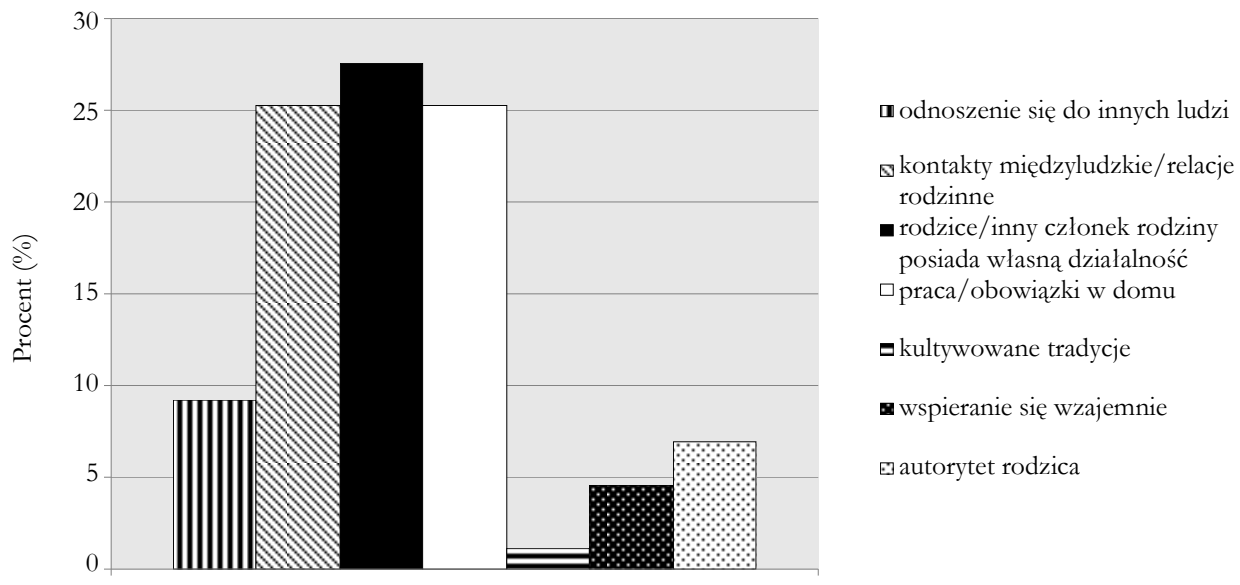

Źródło: opracowanie własne.

${ }^{6}$ Należą do nich: [Marini, 1987, s. 261-274; Roszkowska-Mądra, 2010; Miś, 2010]. 


\subsection{Pogląd o wpływie systemu kształcenia na przedsiębiorczość}

W przeprowadzonych badaniach 95\% respondentów potwierdziło, że wykształcenie i edukacja mają wpływ na przedsiębiorczość. W kształtowaniu postaw przedsiębiorczych młodzież akademicka przypisała $97,9 \%$ wiedzy praktycznej. Studenci uznali, że zdobycie praktycznych umiejętności jest głównym czynnikiem w systemie kształcenia determinującym ich postawy przedsiębiorcze. Spośród ankietowanych studentów 32,7\% wskazało system praktyk studenckich jako najważniejszy czynnik wpływający na kształtowanie ich postaw przedsiębiorczych. Czynnikiem, także często $(24,5 \%)$ wskazanym przez studentów jako najważniejszy w odniesieniu do kształtowania postaw przedsiębiorczości, była wiedza teoretyczna zdobyta w trakcie kształcenia akademickiego, następnie podejście kadry i motywowanie przez nią studentów do działania $(18,4 \%)$, programy nauczania $(12,2 \%)$, czynny udział studentów w pracy kół naukowych $(11,2 \%)$ oraz autorytet nauczyciela $(1 \%)$ - rysunek 6 .

RYSUNEK 6.

Rozkład częstości poglądów młodzieży akademickiej o najważniejszych składnikach systemu kształcenia wpływających na kształtowanie się postaw przedsiębiorczych

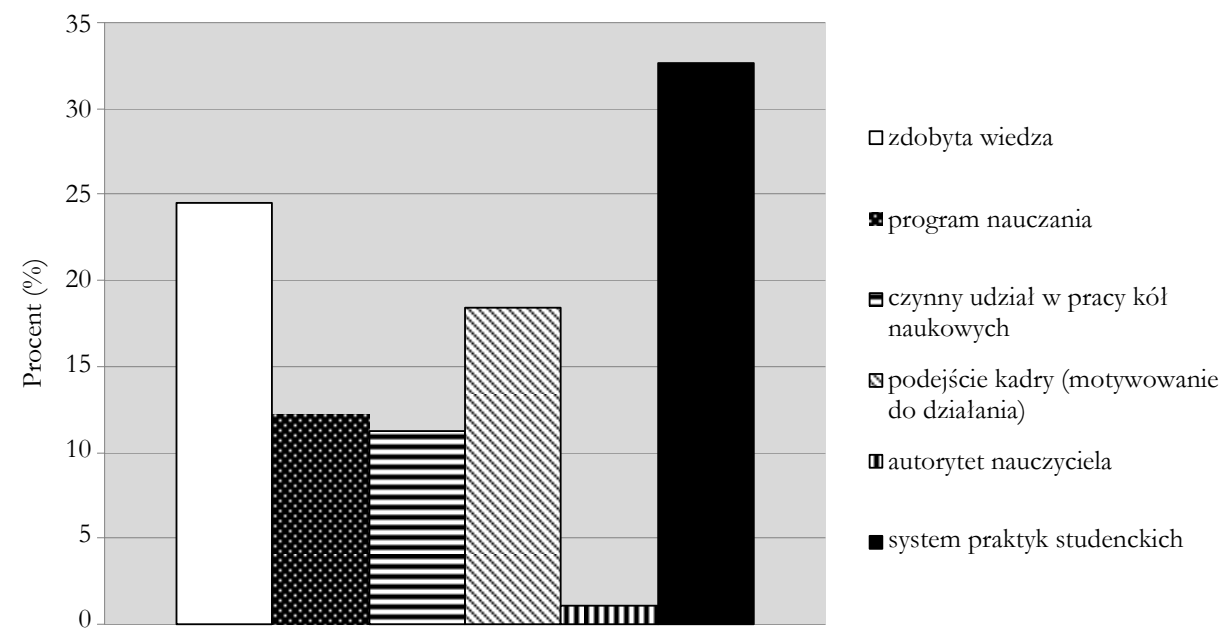

Źródło: opracowanie własne.

\subsection{Pogląd o wpływie doświadczeń zdobytych w trakcie studiów na przedsiębiorczość}

Podczas studiów jest oferowanych wiele możliwości rozwijania postaw przedsiębiorczych u młodzieży akademickiej. W przeprowadzonych badaniach za najistotniejsze doświadczenia zdobyte $\mathrm{w}$ trakcie studiów i wpływające na kształtowanie postaw przedsiębiorczych (w opinii studentów) uznano bardzo często pracę w firmie $(74,8 \%$ ), 
zaś rzadko przebyte szkolenia (10,1\%), działalność w kołach naukowych (8,1\%), działalność w fundacjach lub stowarzyszeniach $(4,0 \%)$ oraz udzielanie się w akcjach społecznych (2,0\%), (rysunek 7.). Wyniki tych badań potwierdzają rolę wiedzy praktycznej (umiejętności) w kształtowaniu postaw przedsiębiorczych młodzieży akademickiej. Studenci doceniają znaczenie współpracy z pracodawcami, jednostkami badawczymi, instytucjami publicznymi w kształtowaniu ich postaw przedsiębiorczych. Stanowi to ważny przyczynek do rozważenia modyfikacji programów studiów i zwrócenia w nich większej uwagi kadry akademickiej na rolę, jaką odgrywają zajęcia praktyczne w edukacji akademickiej.

\section{RYSUNEK 7.}

Rozkład częstości poglądów młodzieży akademickiej o najważniejszych doświadczeniach zdobytych w trakcie studiów wpływających na kształtowanie ich postaw przedsiębiorczych

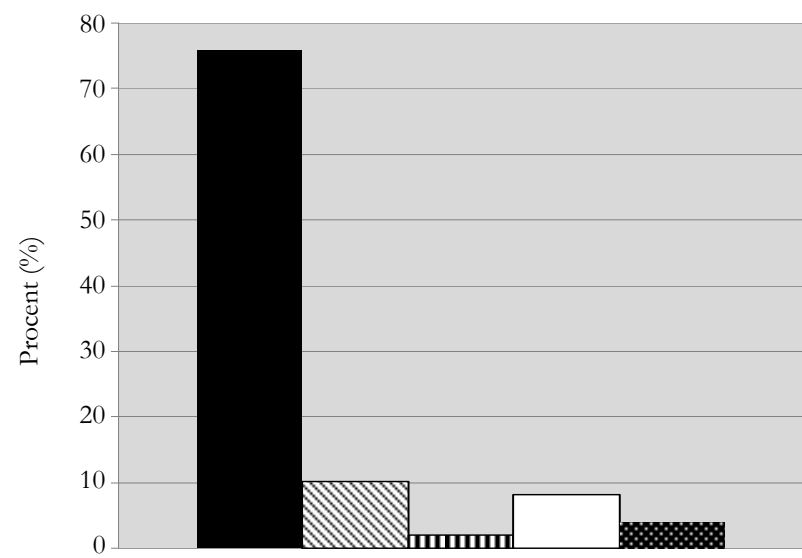

Praca w firmie i system praktyk

ه Przebyte szkolenia

m Udzielanie się w akcjach społecznych

$\square$ Działalność w kołach naukowych

- Działalność w fundacjach/ stowarzyszeniach

Źródło: opracowanie własne.

\section{Podsumowanie}

Wyniki przeprowadzonych analiz wykazały, że młodziė̇ akademicka postrzega przedsiębiorczość głównie przez pryzmat posiadanych umiejętności. Płeć okazała się determinantą warunkującą rozkład poglądów studentów o własnym postrzeganiu przedsiębiorczości, zaś miejsce ich pochodzenia, wiek i kierunek studiów nie różnicowały tych poglądów. Częściej dla kobiet niż mężczyzn ważnym symptomem przedsiębiorczości była postawa, jaką wykazuje dana jednostka i jej umiejętności. Pogląd taki potwierdza Grzegorzewska-Mischka. Jej zdaniem, człowiek, który prezentuje postawę przedsiębiorczą, powinien wyróżniać się odpowiednimi umiejętnościami i właściwymi dla niego cechami, takimi jak: wiara w siebie i optymizm, potrzeba osiagnięć, wytrwałość, otwartość na innych [Grzegorzewska-Mischka, 2010, s. 29]. Tego trzeba się nauczyć i w tym dużą rolę odgrywa wychowanie człowieka i wzorce wyniesione z domu 
rodzinnego. Dom rodzinny jest postrzegany zwykle jako miejsce wzmacniające postawy przedsiębiorcze [Bieniok, 2007, s. 224-235]. Umożliwia on bowiem przekazywanie pozytywnych systemów wartości i przekonań. Przeprowadzone w niniejszym opracowaniu analizy dowiodły, że studenci dostrzegaja znaczenie oddziaływania domu rodzinnego na kształtowanie się ich postaw przedsiębiorczych. Rodzinę spostrzegaja jako ważne środowisko, które jest źródłem doświadczeń. Badani studenci wskazali prowadzenie przez rodzica lub innego członka rodziny własnej działalności gospodarczej jako ważny czynnik sprzyjający rozwijaniu cech przedsiębiorczych. Podobnie oceniono udzielanie się dzieci w pracach i obowiązkach domowych oraz kultywowanie dobrych relacji rodzinnych i międzyludzkich.

Niemalże wszyscy ankietowani (ponad 90\%), wyrażali pogląd, że edukacja oddziałuje na poziom przedsiębiorczości. Na stopień przekonania o ich własnej przedsiębiorczości miały wpływ: płeć, wiek i kierunek studiów. Wykazano, że wraz ze wzrastajacym wiekiem studenci byli częściej przekonani o własnej przedsiębiorczości. Co więcej, ponad 90\% ankietowanych studentów stwierdziło, że edukacja ma wpływ na poziom przedsiębiorczości. Starsi studenci częściej wyrażali pozytywną opinię o wpływie edukacji na przedsiębiorczość. Studenci w wieku 24-26 lat twierdzili tak jednogłośnie. Prowadzone badania o zasięgu międzynarodowym, realizowane przez European Business School oraz Universität St. Gallen w ramach projektu GUESSS - Global University Entrepreneurial Spirit Students' Survey, pokazały, że studenci dopiero po zdobyciu minimalnego doświadczenia zawodowego uzyskuja przekonanie o własnej przedsiębiorczości i objawiają chęć podjęcia własnej działalności gospodarczej. Wskazuje to na doniosłe znaczenie odbywania stażu i systemu praktyk studenckich w trakcie studiów. Badani respondenci uznali, że głównymi czynnikami oddziałującymi na modelowanie ich postaw przedsiębiorczych w systemie kształcenia akademickiego są zdobyte umiejętności praktyczne ( $97,9 \%$ wskazań), które według teorii zasobowej firmy, obok umiejętności teoretycznych, są niezbędnymi zasobami przedsiębiorstwa do tworzenia i utrzymywania przewagi konkurencyjnej na rynku i wobec tego rozwoju przedsiębiorczości. Zatem świadczy to o potrzebie uwzględniania w większym stopniu w planie studiów zajęć praktycznych, co będzie sprzyjać rozwojowi umiejętności praktycznych w trakcie kształcenia akademickiego. Studenci Wydziału Ekonomii i Zarzadzania Uniwersytetu w Białymstoku do najważniejszych doświadczeń, zdobytych w trakcie studiów i oddziałujących na kształtowanie się ich postaw przedsiębiorczych, zaliczali bardzo często doświadczenie uzyskane w trakcie pracy w firmie i w systemie praktyk studenckich $(74,8 \%$ ankietowanych), zaś rzadko udział w przebytych szkoleniach $(10,1 \%)$ i działalność w kołach naukowych $(8,1 \%)$, fundacjach lub stowarzyszeniach $(4,0 \%)$. Natomiast do postulowanych przez studentów Uniwersytetu Ekonomicznego we Wrocławiu działań, jakie powinny podjać uczelnie, aby lepiej przygotować swoich słuchaczy do podjęcia własnej działalności gospodarczej, należały: wprowadzenie przedmiotów przygotowujących do założenia własnej firmy (46,43\% ankietowanych), zapewnienie większej liczby praktyk (44,79\% ankietowanych), organizowanie spotkań z pracodawcami (41\%) i szkoleń dokształcających (39,29\% ankietowanych), [Safin, 2010, s. 47]. Wyniki badań przeprowadzonych wśród studentów Wydziału Ekonomii i Zarządzania Uniwersytetu w Białymstoku również dowodzą potrzeby wprowadzenia do progra- 
mu studiów większej liczby zajęć dydaktycznych o charakterze praktycznym, co pozwoliłoby studentom wzmocnić ich umiejętności praktyczne i podnieść poziom przedsiębiorczości.

\section{Literatura}

Bieniok H. 2007 Ksztaltowanie postaw przedsiębiorcsych mtodzieşy w rodzinie, s₹kole i ucrelni, [w:] Ksztattowanie postaw przedsiebiorczych a edukacja ekonomiczna, P. Wachowiak, M. Dąbrowski, B. Majewski (red.), Fundacja Promocji i Akredytacji Kierunków Ekonomicznych, Warszawa.

Borkowski R. M. 2012 Akademicki Inkubator Przedsiebiorczości instrumentem rozwijania

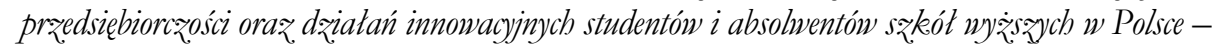
prezentacja mynikón badan, [w:] Mtodzi przedsiebiorcy - inspiracje, koncepcje i unvarunkowania, J. Pasieczny, B. Glinka, A. Brzozowska (red.), Wydawnictwo Naukowe Wydziału Zarządzania Uniwersytetu Warszawskiego, Warszawa.

Brajer-Marczak R., Marciszewska A. 2008 Cåynniki warunkujace pržedsiębiorczość studentów Dolnego Ślaska, „Problemy Zarządzania”, nr 1.

Bratnicki M., J. Strużyna J. 2004 Przedsiebiorcza uyobraźnia zespolenia zpraca, [w:] Prayysztość pracy w XXI wieku, S. Borkowska (red.), IPiSS, Warszawa.

Carree M.A., Thurik A.R., The Impact of Entrepreneurship on Economic Growth, dokument elektroniczny, tryb dostępu: [http://www.hajarian.com/esterategic/tarjomeh/ 2-89-karafariny/1.pdf, data wejścia: 15.05.2014].

Cotis J.-P., Entrepreneurship as an engine for growth: evidence and policy challenges, GEM FOrum Entrepreneurship: Setting the Development Agenda London 10 and 11 January 2007, dokument elektroniczny, tryb dostępu: [http://www.oecd.org/social/ labour/38031895.pdf, data wejścia: 16.05.2014].

Drozdowski G., Przeedsiębiorczosíc w swietle wspótczesnych koncepiji zarzadzania kapitatem ludzkim, dokument elektroniczny, tryb dostępu: [http://bibliotekacyfrowa.pl/ dlibra $/$ docmetadata?id=34638\&from=publication, data wejścia: 3.01 .2014$]$.

Drucker P. 1992 Innowacja i przedsiębiorczość. Praktyka $i$ zasady, Wydawnictwo PWE, Warszawa.

Entrepreneurship, Apr 27th 2009, The Economist, dokument elektroniczny, tryb dostępu: [http://www.economist.com/node/13565718, data wejścia: 28.12.2013].

Fueglistaller U., Klandt H., Halter F., Müller Ch. 2009 Unternehmetrum von Studierenden im international Vergleich Internationaler, St. Gallen und Oestrich-Winkel.

Grzegorzewska-Mischka E. 2010 Wspótczesne uwarunkowania rozwoju præedsiebiorczości w Polsce, Oficyna Wydawnictwa Szkoły Głównej Handlowej w Warszawie, Warszawa.

Jean-Philippe C. 2007 Entrepreneurship as an engine for growth: evidence and policy challenges, dokument elektroniczny, tryb dostępu: [http://www.oecd.org/social/labour/ 38031895.pdf, data wejścia: 16.05.2014]. 
Kirzner I. M. 2008 The Alert and Creative Entrepreneur: A Clarification, IFN Working Paper, no. 760, dokument elektroniczny, tryb dostępu: [http://www.ifn.se/Wfiles/ wp/wp760.pdf, data wejścia: 8.01.2014].

Kłosowski D., Bagiński J., Przedsiebiorczość $i$ sposoby jej pomiaru, Gazeta Innowacje, dokument elektroniczny, tryb dostępu: [http://imik.wip.pw.edu.pl/innowacje11/ strona7.htm, data wejścia: 5.01.2013].

Marciniak M. 2011 Rozwój przedsiębiorczości szansa polskich obszarón wiejskich, Warszawa, dokument elektroniczny, tryb dostępu: [http://www.instytutobywatelski.pl/ 2150/publikacje/raporty/raport-rozwoj-przedsiebiorczosci-szansa-polskich-obsza row-wiejskich, data wejścia: 16.05.2014].

Marini M. 1987 A Typology of Farm Families in Southern Italian Marginal Areas. Multipurpase Agriculture and Forestry, Proceedings of the 11th seminar of the European Association of Agricultural Economists EAAE 28 April 3 May, 1986.

Miś T. 2011 Instytucje doradcze w rozwoju obszarów wiejskich w regionach rozdrobnionego rolnictwa w warunkach integracji europejskiej, Wydawnictwo Uniwersytetu Rzeszowskiego, Rzeszów.

Noga A. 2009 Teorie przedsiebiorstw, Wydawnictwo PWE, Warszawa.

Parker S. C. 2009 The Economics of Entrepreneurship, New York: Cambridge University Press, New York.

Piecuch T. 2010 Przedsiebiorczość. Podstany teoretyczne, Wydawnictwo C.H. Beck, Warszawa.

Pietraszewski M. 2002 Szansa dla przedsiębiorczości, Wydawnictwo eMPI ${ }^{2}$, Poznań.

Przedsiębiorczość akademicka - jak komercjalizować wiedz̨e powstajaca we wroctawskim środowisku naukowym 2010, K. Safin (red.), Wydawnictwo Europa, Wrocław.

Præedsiębiorczość akademicka. Raport z badania, 2009, Warszawa, dokument elektroniczny, tryb dostępu: [http://www.parp.gov.pl/index/more/9701, data wejścia: 28.12.2013].

Raport o stanie sektora matych i średnich przedsiebiorstw w Polsce w latach 2008-2009, 2010, Warszawa, dokument elektroniczny, tryb dostępu: [http://www.parp.gov.pl/ index/more/24313, data wejścia: 15.05.2014].

Raport z. badania Global Entrepreneurship Monitor - Polska 2011, 2012, Warszawa, dokument elektroniczny, tryb dostępu: [http://www.parp.gov.pl/files/74/81/545/ 15203.pdf, data wejścia: 28.12.2013].

Roszkowska-Mądra B. 2010 Obszary wiejskie o niekoryystnych warunkach gospodarowania $w$ aspekcie idei zrónnoważonego rožwoju, Wydawnictwo Uniwersytetu w Białymstoku, Białystok.

The Oxford Handbook of Entrepreneurship 2009, M. Casson, B. Yeung, A. Basu, N. Wadeson (eds.), New York : Oxford University Press, New York.

Wawrzyniak B.M. 2001 Luka edukacyjna bariera procesu integracji polskiej wsi i rolnictwa z. Uniq Europejskaq, „Wieś i Rolnictwo”, nr 3 (112). 